\title{
Immobilizing Metal-Resistant Sulfate-Reducing Bacteria for Cadmium Removal from Aqueous Solutions
}

\author{
Hongguo Zhang, 3, 5, Huosheng $\mathrm{Li}^{2 *}$, Meng Li ${ }^{1}$, Dinggui Luo ${ }^{1,3,4}$, Yongheng Chen ${ }^{2,3}$, \\ Diyun Chen ${ }^{1,4}$, Hailing Luo ${ }^{1}$, Zhenxin Chen ${ }^{1}$, Keke Li ${ }^{1}$ \\ ${ }^{1}$ School of Environmental Science and Engineering, Guangzhou University, Guangzhou, China \\ ${ }^{2}$ Collaborative Innovation Center of Water Quality Safety and Protection in Pearl River Delta, \\ Guangzhou University, Guangzhou, China \\ ${ }^{3}$ Key Laboratory for Water Quality and Conservation of the Pearl River Delta, Ministry of Education, \\ School of Environmental Science and Engineering, Guangzhou University, Guangzhou, China \\ ${ }^{4}$ Guangdong Provincial Key Laboratory of Radionuclides Pollution Control and Resources, School of Environmental \\ Science and Engineering, Guangzhou University, Guangzhou, China \\ ${ }^{5}$ Guangzhou University-Linköping University Research Center on Urban Sustainable Development, \\ Guangzhou University, Guangzhou, China
}

Received: 12 September 2017

Accepted: 20 January 2018

\begin{abstract}
Immobilized sulfate-reducing bacteria (SRB) in polyvinyl alcohol (PVA)-sodium alginate matrix were applied as biosorbents to remove cadmium $(\mathrm{Cd})$ from aqueous solutions. Multiple characterization techniques including scanning electron microscope (SEM)-energy dispersive spectrometer (EDS), and Fourier transform infrared (FT-IR) spectra indicate that immobilized beads provided a suitable microenvironment for SRB. Performance tests show that $\mathrm{Cd}$ removal was highly affected by $\mathrm{pH}$ value and temperature, with optimum temperature at $35^{\circ} \mathrm{C}$ and $\mathrm{pH}$ value of 8.0. A pseudo second-order model was applied to describe the adsorption kinetic. FT-IR and x-ray photoelectron spectroscopy (XPS) analyses imply that biosorption, sulfide, and hydroxide precipitation are the main mechanisms for removing Cd. The immobilized SRB beads have great potential for remediating Cd-containing wastewater.
\end{abstract}

Keywords: sulfate-reducing bacteria, immobilization, cadmium, adsorption, heavy metals

\section{Introduction}

Owing to the rapid development of industry, the resulting huge amount of wastewater containing heavy

*e-mail: hilihuo@163.com metals has posed a serious challenge to environmental protection. Among heavy metals, cadmium $(\mathrm{Cd})$ is one of the most hazardous materials affecting the environment [1]. As an element of multiple industrial purposes, $\mathrm{Cd}$ is widely used in modern industries such as nickel-cadmium batteries, pigments, alloys, phosphate fertilizers, pesticides, textile operations, metal plating, 
and refining industries [2-3]. According to World Health Organization guidelines, the permissible $\mathrm{Cd}$ content of drinking water is $0.003 \mathrm{mg} / \mathrm{L}$ [4-5]. Excessive discharge of $\mathrm{Cd}$ into waterways by various industrial activities endangers the environment and human health due to its toxicity, even at low concentrations, bioaccumulation tendency, and persistency in nature [6]. It is reported that excessive $\mathrm{Cd}$ ingestion can lead to severe human illness such as kidney disease, skeletal damage, or even cancer [7]. Hence, it is necessary to treat the wastewater before discharge.

A variety of treatment technologies such as chemical precipitation, coagulation/ flocculation, ion exchange, solvent extraction, membrane filtration, and adsorption have been developed for $\mathrm{Cd}$ removal [8]. Among various $\mathrm{Cd}$ removal techniques, biological sulfate reduction, which combines biosorption, bioaccumulation, and precipitation in one technique, has emerged as an effective solution for removing toxic heavy metals (including $\mathrm{Cd}$ ) from wastewater [9]. In comparison with conventional approaches, it was cost-effective, efficient, and stable for heavy metals removal. The use of sulfate-reducing bacteria (SRB) in anaerobic sulfate reduction not only is capable of removing heavy metals (including $\mathrm{Cd}$ ), but also is efficient in removing sulfate and organic carbon, which are typical pollutants in acid mine drainage [10]. The SRB can reduce sulfate to sulfide, which is an efficient precipitant to form metal sulfide of low solubility [11-13]. Therefore, the SRB may provide an excellent choice for removing toxic $\mathrm{Cd}$ from the aqueous phase.

However, traditional heavy metal removal processes via SRB have several shortcomings, including low metal concentration tolerance in the medium aqueous solution, poor cell retention within continuous bioreactors, and vulnerability to environmental factors, etc. [14-16]. Biological immobilization approaches involved with a gel-like medium that retains the SRB in a particular space have attracted increasing attention for their high efficiency, strong reactivity, and stability [17-18]. In this sense, theoretically, $\mathrm{Cd}$ toxicity in the aqueous solution could be reduced, hence improving $\mathrm{Cd}^{2+}$ removal capacity. However, very few studies have been carried out to investigate the application of immobilized SRB for biogenic $\mathrm{Cd}$ removal.

In this work, immobilization of a non-traditional SRB in a polyvinyl alcohol (PVA) gel matrix was applied to remove $\mathrm{Cd}$ from aqueous solution. Moreover, the effects of $\mathrm{pH}$ and temperature on $\mathrm{Cd}^{2+}$ removal were investigated. The biosorption kinetics of $\mathrm{Cd}$ removal in immobilized beads was also examined. Scanning electronic microscopy (SEM), Fourier transform infrared spectroscopy (FTIR), and x-ray photoelectron spectroscopy (XPS) were applied to explore the $\mathrm{Cd}$ removal mechanism.

\section{Materials and Methods}

\section{Preparing Immobilized Beads}

Analytical-grade chemicals and reagents were used in all the experiments unless otherwise specified. SRB were prepared as described previously [19]. Briefly, culture media of SRB were composed of (per liter of deionized water): $0.5 \mathrm{~g} \mathrm{Na}_{2} \mathrm{SO}_{4}, 2.0 \mathrm{~g} \mathrm{MgSO}_{4}, 1.5 \mathrm{~g} \mathrm{KH}_{2} \mathrm{PO}_{4}, 0.1 \mathrm{~g}$ $\mathrm{NH}_{4} \mathrm{Cl}, 0.5 \mathrm{~g}$ cysteine hydrochloride, $1 \mathrm{~g}$ yeast extract, $0.1 \mathrm{~g} \mathrm{CaCl}_{2}, 0.3 \mathrm{~g}$ sodium citrate, $0.1 \mathrm{~g}$ ascorbic acid, and $2.0 \mathrm{~g}$ sodium lactate. The PVA (with 99.4-99.8\% saponification), sodium chloride, sodium alginate, and silica used in this study were supplied by Damao chemical reagent factory (Tianjin, China). A filter-sterilized solution of $\mathrm{Cd}\left(\mathrm{NO}_{3}\right)_{2}$ (AR Grade, Guangdong Analysis and Testing Center, China) was used as the source of $\mathrm{Cd}$. All other chemicals used in this study were supplied by Zhiyuan chemical reagent factory (Tianjin, China).

The immobilized bacteria used were described elsewhere [13], and immobilized beads were prepared by an entrapping method [20]. Immobilization of biomass via entrapment was carried out as follows: Firstly, the polyvinyl alcohol solution $(6 \%, \mathrm{w} / \mathrm{v})$, silica solution $(3 \%$, $\mathrm{w} / \mathrm{v})$, and sodium alginate solution $(0.5 \%, \mathrm{w} / \mathrm{v})$ were dissolved in deionized water and mixed thoroughly. Secondly, activated carbon solution $(1 \%, \mathrm{w} / \mathrm{v})$ and SRB diluted solution $(35 \%, \mathrm{w} / \mathrm{v})$ were added into the colloid and mixed evenly at $40^{\circ} \mathrm{C}$. The alginate-biomass mixture was then injected with a $10 \mathrm{ml}$ syringe into a $100 \mathrm{ml}$ $\mathrm{CaCl}_{2}(1 \%$, w/v) solution for polymerization.

\section{Biosorption Experiments}

We conducted biosorption experiments including influencing factors of $\mathrm{pH}$ and temperature, the kinetics and isotherms. During each test, $1 \mathrm{~g}$ beads (dry weight) containing $0.015 \mathrm{~g} \mathrm{SRB}$ (dry weight) were added to a flask containing $100 \mathrm{ml}$ of Cd-bearing solution. Temperature was controlled by shaking Baths (Jintan, SHZ-88, China), and $\mathrm{pH}$ value was adjusted with $0.01 \mathrm{M} \mathrm{HCl}$ and $0.01 \mathrm{M} \mathrm{NaOH}$. Samples were taken after $24 \mathrm{~h}$ reaction. All adsorption experiments were conducted in triplicate. Mean value and standard deviation of the results were calculated to obtain reliable data. Cd concentration was determined by flame atomic absorption spectrometry (FAAS, TAS990, China).

\section{Calculation}

The metal uptake capacity $q_{\mathrm{e}}\left(\mathrm{mg} \cdot \mathrm{g}^{-1}\right)$ was calculated by the following mass balance equation:

$$
q_{e}=\frac{\left(C_{0}-C e\right) V}{m}
$$




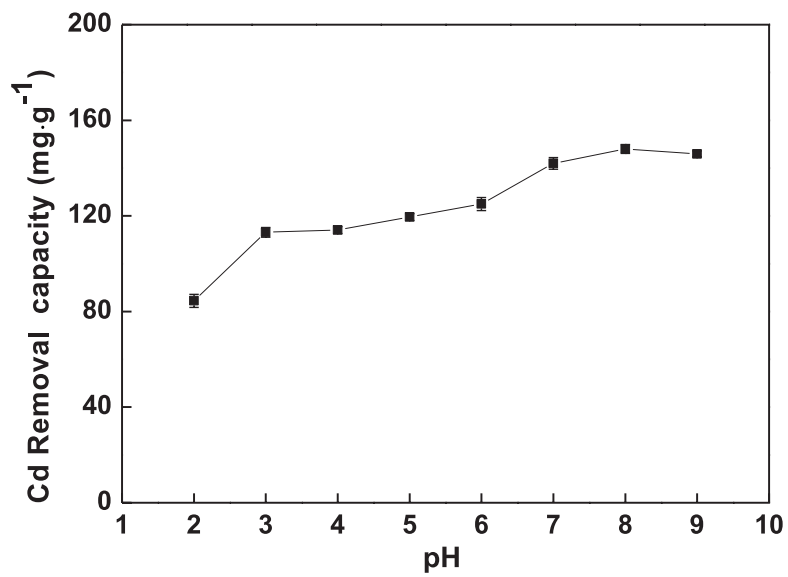

Fig. 1. Effect of $\mathrm{pH}$ on $\mathrm{Cd}$ removal using PVA-SRB beads.

...where $C_{0}$ was the initial $\mathrm{Cd}$ concentration $\left(m g \cdot g^{-1}\right), C_{e}$ was the $\mathrm{Cd}$ concentration at equilibrium $\left(m g \cdot g^{-1}\right), V$ was the volume of solution (L), and $m$ was the dry weight of SRB (g).

For biosorption kinetics, several kinetic models, including Lagergren pseudo first-order (LPFO), Lagergren pseudo second-order (LPSO), and intraparticle diffusion model (IPD) were used to describe the $\mathrm{Cd}$ removal dynamic over the entire reaction time. The relevant equations are generally expressed as follows [21]:

$$
\begin{gathered}
\ln \left(q_{e}-q_{t}\right)=\ln q_{e}-k_{1} t \\
\frac{t}{q_{t}}=\frac{1}{k_{2} q_{e}^{2}}+\frac{t}{q_{e}} \\
q_{t}=k_{3} t^{\frac{1}{2}}+C
\end{gathered}
$$

...where $q_{\mathrm{e}}$ and $q_{\mathrm{t}}$ are the removal amounts at equilibrium and time $t\left(\mathrm{mg} \mathrm{g}^{-1}\right), k_{1}$ is the LPFO constant $\left(\mathrm{min}^{-1}\right), k_{2}$ is

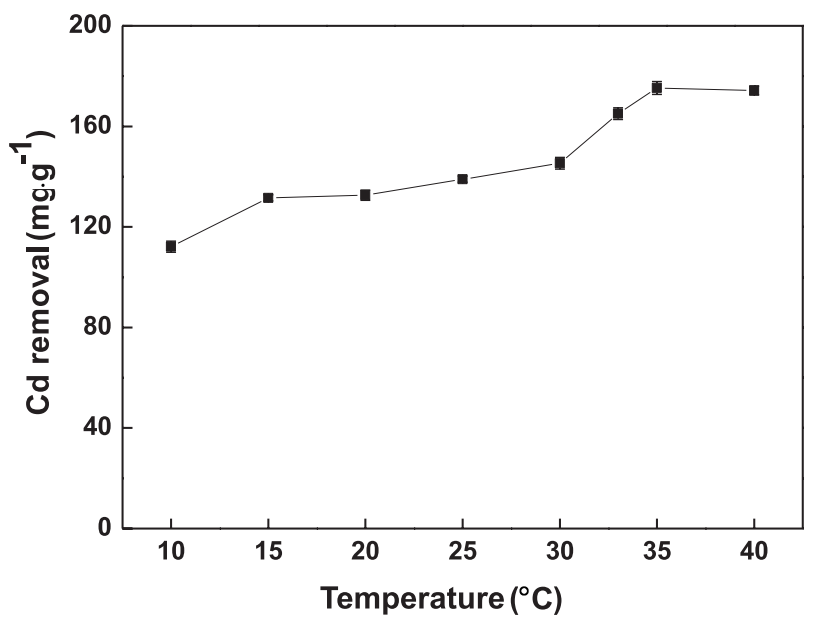

Fig. 2. Effect of temperature on Cd removal using PVA-SRB beads. the LPSO constant $\left(\mathrm{g} \cdot \mathrm{mg}^{-1} \cdot \mathrm{min}^{-1}\right), k_{3}$ is the IPD constant $\left(\mathrm{mg} \cdot \mathrm{g}^{-1} \cdot \mathrm{min}^{-1 / 2}\right.$ ), and $C$ is a constant. The corresponding rate constants and coefficients for Eqs 2-4 were calculated through linear fitting of $\ln \left(q_{e}-q_{t}\right)$ versus time $t, t / q_{t}$ versus time $t$, and $q_{t}$ versus time $t^{1 / 2}$, respectively.

For isotherm tests, Langmuir (Eq. (5)) and Freundlich (Eq. (6)) models were used to describe the adsorption isotherms:

$$
q_{e}=\frac{\mathrm{Q}_{0} \mathrm{~K}_{\mathrm{L}} C_{e}}{1+\mathrm{K}_{\mathrm{L}} C_{e}}
$$
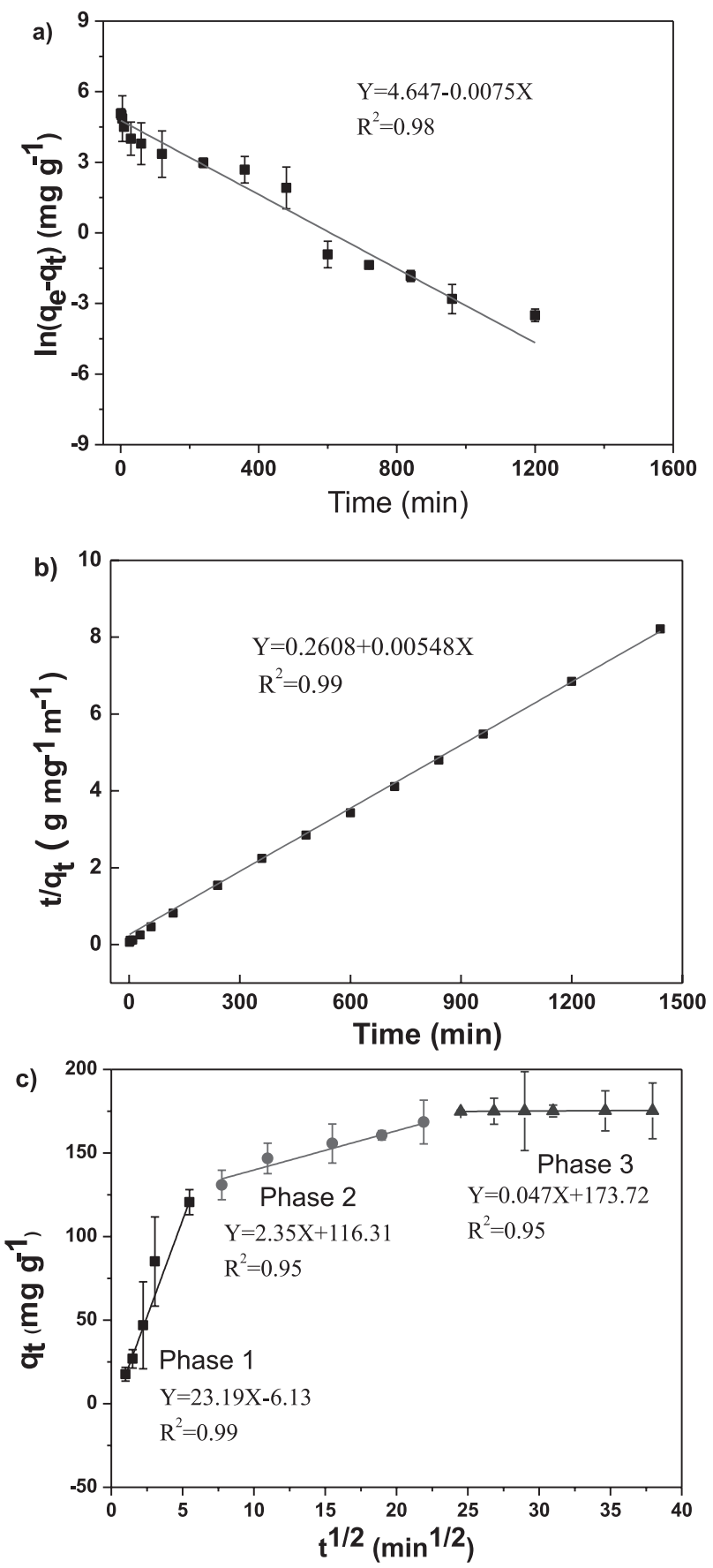

Fig. 3. The kinetic fitting curves of a) LPFO, b) LPSO, and c) IPD models. 
Table 1. Kinetic parameters of LPFO, LPSO, and IPD for Cd removal by immobilized SRB.

\begin{tabular}{|c|c|c|c|c|c|}
\hline \multirow{2}{*}{ Coefficients } & \multirow{2}{*}{ LPFO } & \multirow{2}{*}{ LPSO } & \multicolumn{3}{|c|}{ IPD } \\
\cline { 4 - 6 } & & & $\begin{array}{c}\text { Phase } \\
1\end{array}$ & $\begin{array}{c}\text { Phase } \\
2\end{array}$ & $\begin{array}{c}\text { Phase } \\
3\end{array}$ \\
\hline$k_{1}$ & $7.87 \times 10^{-3}$ & - & - & - & \\
\hline$q_{\mathrm{e}}$ & 119.22 & - & - & - & \\
\hline$k_{2}$ & - & $1.14 \times 10^{-4}$ & - & - & \\
\hline$q_{\mathrm{e}}$ & - & 183.49 & - & - & \\
\hline$k_{3}$ & - & - & 23.19 & 2.35 & 0.047 \\
\hline$C$ & - & - & -6.13 & 116.31 & 173.72 \\
\hline$R^{2}$ & 0.98 & 0.99 & 0.99 & 0.95 & 0.95 \\
\hline
\end{tabular}

...where $Q_{0}$ is the saturated monolayer sorption capacity $(\mathrm{mg} / \mathrm{g})$ and $K_{L}$ is the Langmuir isotherm constant that relates to the energy of adsorption $(\mathrm{L} / \mathrm{mg})$.

$$
\mathrm{q}_{\mathrm{e}}=K_{f} \mathrm{C}_{\mathrm{e}}^{\frac{1}{\mathrm{n}}}
$$

...where $K_{\mathrm{f}}$ and $n$ are the Freundlich constants related to the adsorption amount and adsorption intensity of the sorbent, respectively.

\section{Characterizing Immobilized SRB}

The morphology of immobilized beads before and after $\mathrm{Cd}$ removal was characterized by scanning electron microscope (SEM) and energy dispersive spectrometer (EDS) (JSM7001F, JEOL Ltd., Japan). FTIR Spectra of $\mathrm{Cd}$ biosorption on immobilized beads were recorded using an FTIR spectrometer (Tensor27, Bruker, Germany) equipped with a $\mathrm{KBr}$ beam splitter and a DTGS detector.

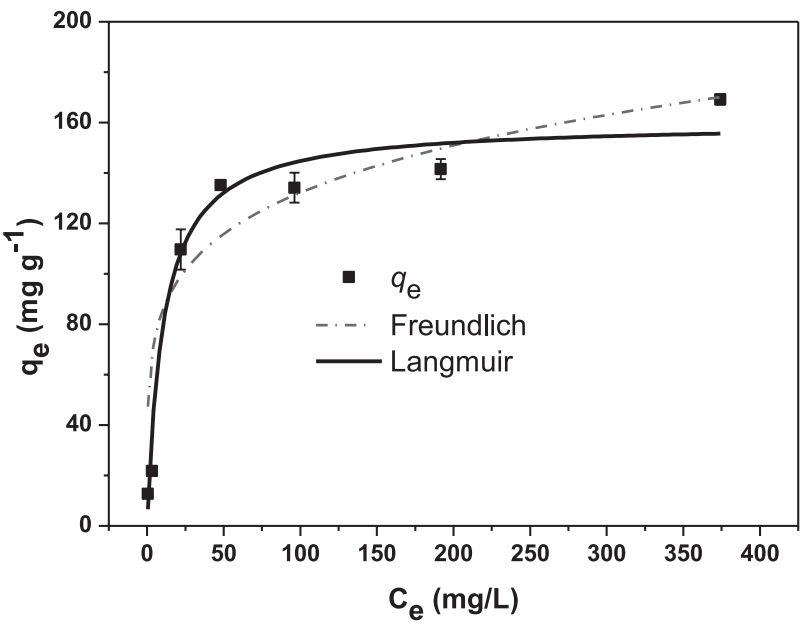

Fig. 4. The fitting of the Langmuir and Freundlich isotherm models.
Table 2. Isotherm parameters of the Langmuir and Freundlich models.

\begin{tabular}{|c|c|c|}
\hline Coefficients & Langmuir & Freundlich \\
\hline$Q_{0}\left(\mathrm{mg} \cdot \mathrm{g}^{-1}\right)$ & 160.0 & - \\
\hline$K_{\mathrm{L}}\left(\mathrm{L} \cdot \mathrm{mg}^{-1}\right)$ & 0.095 & - \\
\hline$K_{\mathrm{f}}$ & - & 55 \\
\hline$n$ & - & 5.25 \\
\hline$R^{2}$ & 0.97 & 0.79 \\
\hline
\end{tabular}

X-ray diffraction (XRD) analysis was carried out on a PW3040/60(PANalytical, Neitherland) analyzer. X-ray photoelectron spectroscopy (XPS) was carried out with monochromatic $\mathrm{Al} \mathrm{K} \alpha$ radiation $(h v=1486.6 \mathrm{eV}$; Kratos Axis Ultra, Japan) to identify the element and compounds of the adsorbents. All binding energy (BE) was referenced to $284.6 \mathrm{eV}$ of C 1s peak [22].

\section{Results and Discussion}

\section{Effect of $\mathrm{pH}$ and Temperature}

The removal of $\mathrm{Cd}$ was low at $\mathrm{pH} 2.0$ and then improved with the increasing $\mathrm{pH}$ from 2.0 to 8.0, reaching a peak capacity of $175.3 \mathrm{mg}^{-1}$ at $\mathrm{pH} 8.0$ (Fig. 1). A further increase in $\mathrm{pH}$ to 9.0 led to a slight decline in $\mathrm{Cd}$ removal to $174.3 \mathrm{mg} \cdot \mathrm{g}^{-1}$. The reaction $\mathrm{pH}$ significantly affecting the activity of SRB and the solubility of sulfide [23] plays an important role in the bioprocess of removing heavy metal [24]. This is because the activity of bacteria was inhibited at low $\mathrm{pH}[13,25]$. In addition, under low $\mathrm{pH}(<7.0)$, most sulfide exists in the form of $\mathrm{H}_{2} \mathrm{~S}$, which may strongly affect the SRB and is ineffective in precipitation of $\mathrm{Cd}$. With increased $\mathrm{pH}$ from 2.0 to 8.0 , the activity of SRB became higher. Furthermore, under $\mathrm{pH}$ above 8.0, the sulfide exists mainly in the forms of $\mathrm{HS}^{-}$and $\mathrm{S}^{2-}$, which are effective in removal of metal ions, including $\mathrm{Cd}$ via precipitation. Therefore, the precipitation of cadmium ions and biosorption of $\mathrm{Cd}$ played synergetic roles for cadmium removal from aqueous solution with increased $\mathrm{pH}$ values. However, sulfate reduction by SRB would be restrained due to $\mathrm{pH}$ value beyond optimum range, and the role of bio-precipitation was partly offset [26]. Therefore, a little descent in $\mathrm{Cd}$ biosorption capacity was observed at pH 9.

The effect of temperature on $\mathrm{Cd}$ removal was also investigated. The $\mathrm{Cd}$ removal capacity increased from $84.5 \mathrm{mg} \cdot \mathrm{g}^{-1}$ to $148.0 \mathrm{mg} \cdot \mathrm{g}^{-1}$, when temperature increased from $10^{\circ} \mathrm{C}$ to $35^{\circ} \mathrm{C}$, and decreased slightly to $145.9 \mathrm{mg} \cdot \mathrm{g}^{-1}$ when the temperature was raised further up to $40^{\circ} \mathrm{C}$ (Fig. 2). Removal capacity of the immobilized SRB increased with the rise of temperature due to enhanced protonation and deprotonation rate of functional groups, together with increased activity 

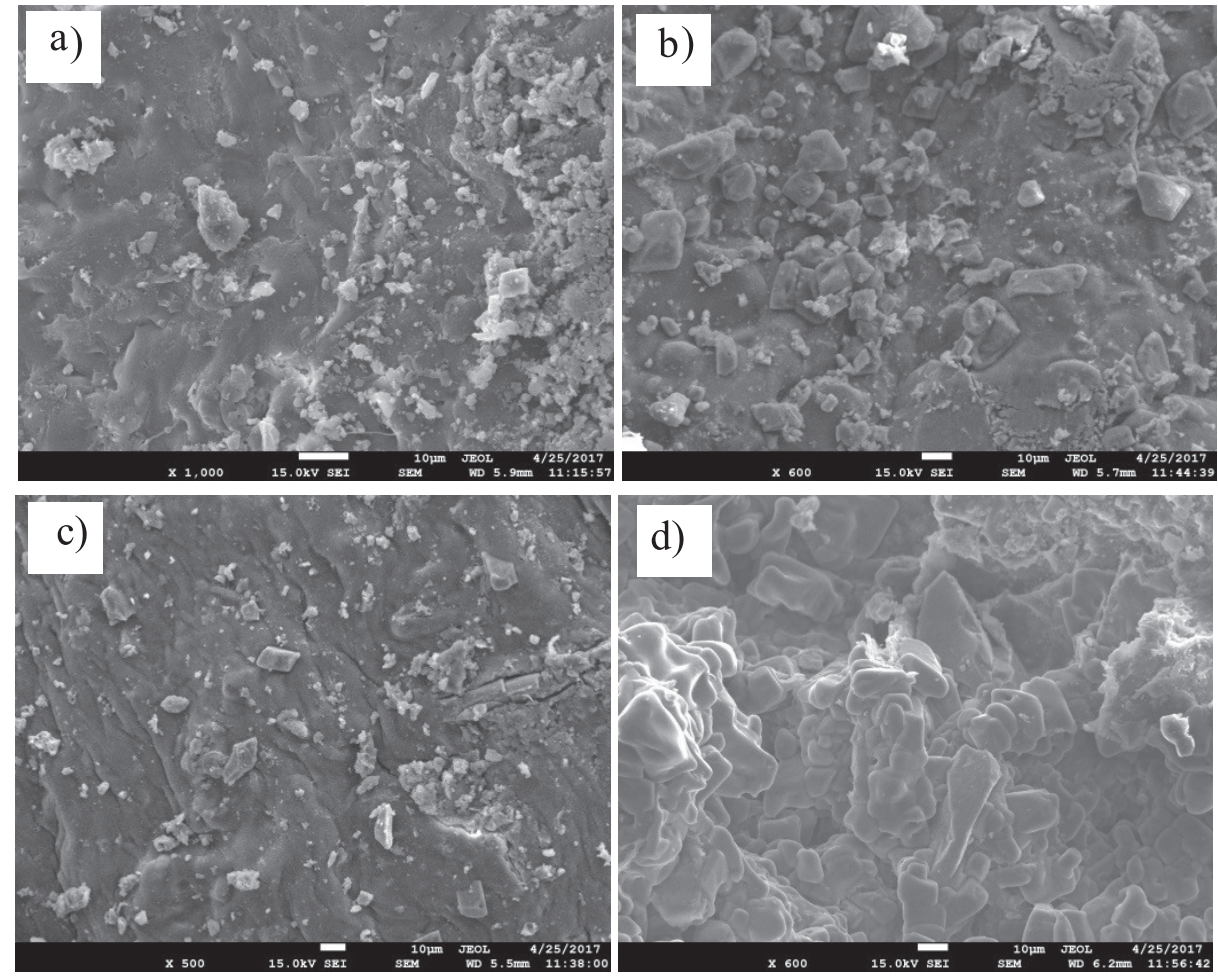

Fig. 5. SEM photographs of immobilized beads: a) and b) were the surface and cross-section photograph of blank beads, c) and d) were the surface and cross-section photograph of immobilized beads after biosorption.

of SRB at higher temperature [27]. However, it has been revealed that when the temperature is higher than $35^{\circ} \mathrm{C}$, the activity of SRB can usually be inhibited because of protein denaturation and inactivation of bacteria [28]. Our findings are consistent with previous reports (Fig. 2).

\section{Biosorption Kinetic Study}

All three kinetic models (LPFO, LPSO and IPD) were well fitted to the $\mathrm{Cd}$ removal profile by immobilized SRB (Fig. 3). The highest goodness of linear fitting was achieved by LPSO, followed by LPFO and IPD models (Table 1). It is usually revealed that LPSO was most appropriate to describe biosorption [29-30] and physicochemical adsorption [31] kinetics for heavy metals removal. The $\mathrm{Cd}$ removal capacity $\left(119.22 \mathrm{mg} \cdot \mathrm{g}^{-1}\right.$, Table 1) calculated via LPFO fitting accounted for $70 \%$ of the maximum experimental one $\left(169.21 \mathrm{mg} \cdot \mathrm{g}^{-1}\right)$, while the calculated $\mathrm{Cd}$ removal capacity accounted for $108 \%$ of the maximum experimental one, which is close to the actual experimental outcome, further indicating that the LPSO model best described the Cd adsorption by immobilized SRB.

For the IPD kinetic model, the biosorption process can be divided into membrane diffusion phase, internal diffusion phase, and biosorption reaction stage, and total biosorption rate was mainly controlled by membrane diffusion, internal diffusion, or both [32]. Our results were closely in line with this three-stage adsorption hypothesis (Fig. 3c). In order to further investigate the biosorption mechanism of immobilized SRB for Tl removal, the kinetic data were fitted with IPD. In this study, the rate parameter $\left(k_{3}\right)$ in Phase 1 is greater than that in the latter two phases, which implies that the membrane diffusion phase was the rate-determining step for Cd removal by immobilized SRB (Table 1).

\section{Biosorption Isotherms}

The Langmuir model was better fitted than Freundlich to describe the isotherms of $\mathrm{Cd}$ biosorption by immobilized SRB (Fig. 4 and Table 2), as the correlation coefficient of Langmuir is much higher than that of Freundlich. The obtained $\mathrm{Cd}$ removal capacity is higher than that reported by López Pérez and Aguilar López [33], in which Desulfovibrio alaskensis (one species of SRB) was used as a biosorbent for maximum $\mathrm{Cd}$ removal of $88 \mathrm{mg} \cdot \mathrm{g}^{-1}$. The $\mathrm{Cd}$ removal capacity was also higher than other biosorbents such as algal [34-35] and bacterial [36] materials, implying the great potential of this technique for $\mathrm{Cd}$ removal application.

\section{Characterizing Immobilized SRB \\ Morphologies of Immobilized Beads XRD Analysis}

There were two strong peaks centered at $2 \theta$ of $20.8^{\circ}$ and $26.7^{\circ}$ (Fig. 6). The major strong peaks were ascribed to the higher-order degree of cellulose crystalline structure, 


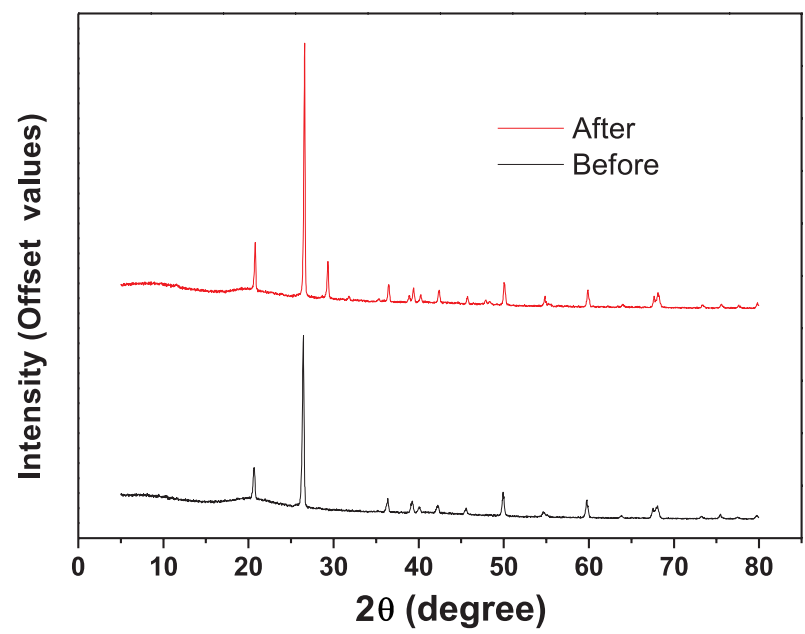

Fig. 6. XRD spectra of immobilized beads before and after biosorption.

and the minor broad peaks were due to lower-order degree of polysaccharides structure. Some new peaks ( $2 \theta$ of $29.4^{\circ}$ ) emerged after biosorption, likely implying the presence of CdS [37], which was the precipitate $\left(K_{\mathrm{sp}}=8.0 \times 10^{-27}\right)$ formed due to sulfate reduction reaction by the immobilized SRB.

\section{FTIR Analysis}

The FTIR analysis was used to characterize the changes of functional groups before and after $\mathrm{Cd}$ biosorption (Fig. 7). The strong and broad peaks at $2,900 \mathrm{~cm}^{-1}$ to $3,500 \mathrm{~cm}^{-1}$ was assigned to the $\mathrm{O}-\mathrm{H}$ stretching vibration [38]. The intensity of several peaks from $1,078 \mathrm{~cm}^{-1}$ to $1,880 \mathrm{~cm}^{-1}$ became weaker together with the blue-shift $\left(1,078 \mathrm{~cm}^{-1}\right.$ to $1,084 \mathrm{~cm}^{-1}, 1,385 \mathrm{~cm}^{-1}$ to $1,420 \mathrm{~cm}^{-1}, 1,629 \mathrm{~cm}^{-1}$ to $\left.1,635 \mathrm{~cm}^{-1}\right)$ after adsorption was likely due to that fact that PVA and sodium alginate reacted with metal ions to form carboxylate compounds [13]. The peak of $1,385 \mathrm{~cm}^{-1}$ shifted to $1,420 \mathrm{~cm}^{-1}$,

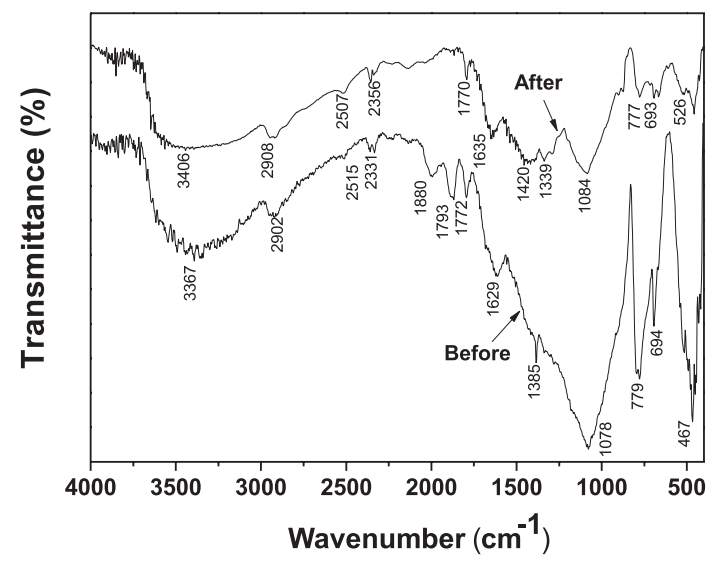

Fig. 7. FT-IR spectra of immobilized beads before and after biosorption.
Table 3. EDS analysis of the immobilized beads before and after biosorption.

\begin{tabular}{|c|c|c|}
\hline Elements & Before (wt,\%) & After (wt,\%) \\
\hline $\mathrm{C}$ & 55.36 & 45.22 \\
\hline $\mathrm{O}$ & 44.64 & 53.83 \\
\hline $\mathrm{S}$ & 0.00 & 0.50 \\
\hline $\mathrm{Cd}$ & 0.00 & 0.46 \\
\hline Total & 100.00 & 100.00 \\
\hline
\end{tabular}

corresponding to $\mathrm{O}-\mathrm{H}$ deformation vibration from the hydroxyl groups of PVA. The intensity was weaker, implying that the amount of hydroxyl groups decreased when $\mathrm{Cd}$ was laden to the biosorbents. The intensity of the peak from $467 \mathrm{~cm}^{-1}$ to $694 \mathrm{~cm}^{-1}$ transformed and some of the peaks disappeared, indicating that sulfate was reduced to sulfide that later reacted with $\mathrm{Cd}^{2+}$ to form CdS precipitation [39]. FTIR Spectral analysis shows that sulfate reduction played an important role in Cd removal.

\section{XPS Analysis}

The Cd and sulfur components were observed after adsorption (Fig. 8a), indicating the successful capture of $\mathrm{Cd}$ by sulfate reduction. The S2p core level XPS spectra show that there is little $\mathrm{S}$ content in the immobilized beads before adsorption, while $\mathrm{S}$ content appeared in the immobilized beads after adsorption (Fig. 8b). The peaks at $161.40 \mathrm{eV}, 164.05 \mathrm{eV}$, and $168.71 \mathrm{eV}$ were assigned to sulfide [40-42], sulfur [43], and sulfate [44], respectively. The proportions of the sulfide, sulfur, and sulfate were $12.5 \%, 30.1 \%$, and $56.7 \%$, respectively. The $\mathrm{Cd} 3 \mathrm{~d}$ core level spectra suggest that there is no Cd detected before adsorption (Fig. 8c). The peaks at $405.17 \mathrm{eV}$ and $407.24 \mathrm{eV}$ were attributed to $\mathrm{CdS}$ and $\mathrm{CdO}$ [45-46], respectively. The peak at $411.95 \mathrm{eV}$ was ascribed to the spectra for $\mathrm{Cd}(\mathrm{II}) 3 / 2$ [45, 47]. Therefore, the precipitation of $\mathrm{Cd}$ as cadmium hydroxide might also take place. The O1s core level spectra indicate that a small fraction $(1.50 \%)$ of the metal oxide group (Me-O) at $529.6 \mathrm{eV}$ [31] ascribed to alginate $(\mathrm{NaO})$ and $\mathrm{SiO}_{2}$ was present. The $\mathrm{C}=\mathrm{O}$ peak at $531.20 \mathrm{eV}(33.29 \%)$ and the $\mathrm{C}-\mathrm{O}$ peak at $532.10 \mathrm{eV}$ (35.74\%) [48] from the PVA and alginate were dominant. The OH group at $532.80 \mathrm{eV}(29.47 \%)$ [31] owing to the alginate and PVA was also identified. After adsorption, the Me-O group slightly increased due to the formation of $\mathrm{CdO}$, which is consistent with the outcome of $\mathrm{Cd} 3 \mathrm{~d}$ core level spectra.

\section{Conclusions}

Immobilized SRB are potential potent biosorbents for removing $\mathrm{Cd}(\Pi)$ from aqueous solution. The $\mathrm{pH}$ and temperature of the solution had strong effects on 

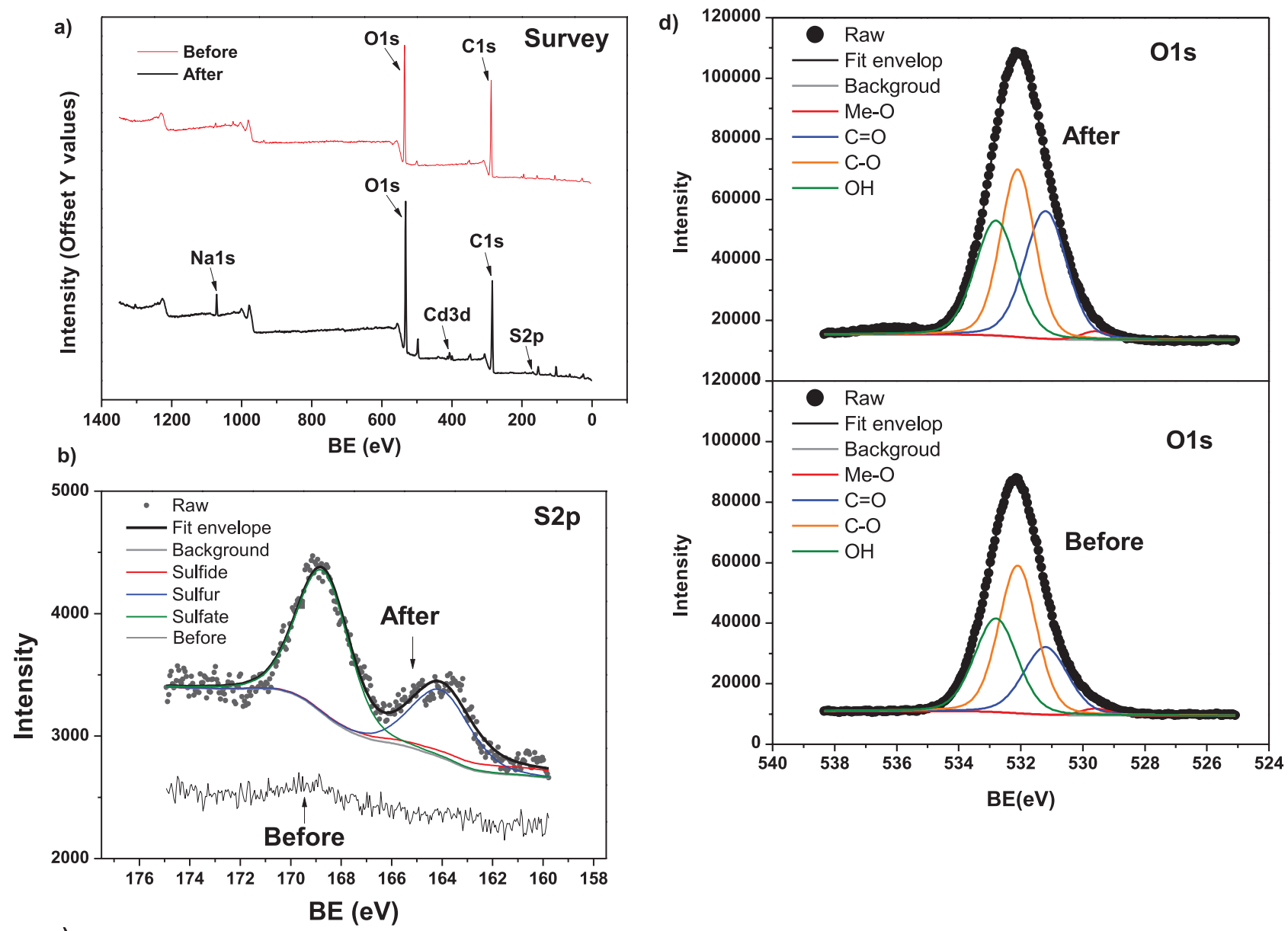

c)

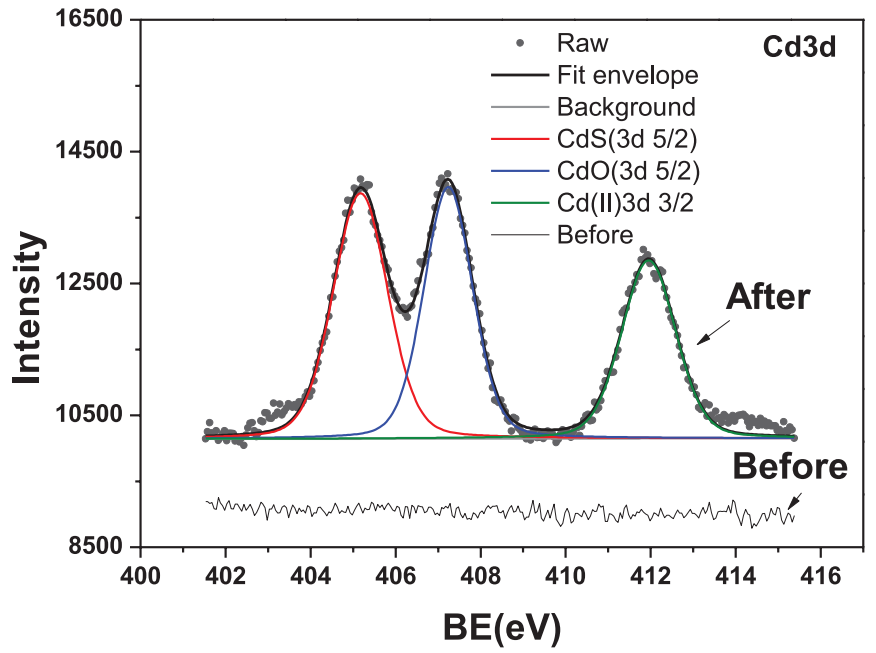

Fig. 8. XPS spectra of the immobilized beads before and after adsorption: a) survey, b) S2p core level, c) Cd3d core level, and d) O1s core level region.

$\mathrm{Cd}(\Pi)$ removal, and the optimum temperature and $\mathrm{pH}$ value were $35^{\circ} \mathrm{C}$ and 8.0 , respectively. A suitable microenvironment for the SRB was created by immobilization. The LPSO model could be well fitted to $\mathrm{Cd}(\Pi)$ biosorption by immobilized beads. Biosorption and sulfide precipitation are the main mechanisms for $\mathrm{Cd}(\mathrm{II})$ removal.

\section{Acknowledgements}

Our work was supported by the National Natural Science Foundation (51208122, 41372248, 51778156, 51708142), New Technological Star Project of Pearl River (2011061), Science and Technology Program of Guangzhou (201707010256), a high-level university 
construction project, the Significant Innovation Project of the Bureau of Guangzhou Municipality (13XT02), the Foundation for Fostering the Scientific and Technical Innovation of Guangzhou University, the Department of education of Guangdong Province (2015KQNCX115), and the Guangzhou Education Bureau (1201630390).

\section{References}

1. ZHU X., SONG T., LV Z., JI G. High-efficiency and low-cost $\alpha-\mathrm{Fe}_{2} \mathrm{O}_{3}$ nanoparticles-coated volcanic rock for $\mathrm{Cd}(\mathrm{II})$ removal from wastewater. Process Safety and Environmental Protection. 104, 373, 2016.

2. CARRILLO ZENTENO M.D., DE FREITAS R.C.A., FERNANDES R.B.A., FONTES M.P.F., JORD O, C.P. Sorption of Cadmium in Some Soil Amendments for In Situ Recovery of Contaminated Soils. Water, Air, \& Soil Pollution. 224 (2), 1418, 2013.

3. KUMAR R., CHAWLA J. Removal of Cadmium Ion from Water/Wastewater by Nano-metal Oxides: A Review. Water Quality, Exposure and Health. 5 (4), 215, 2014.

4. BASU M., GUHA A.K., RAY L. Adsorption Behavior of Cadmium on Husk of Lentil. Process Safety and Environmental Protection. 106, 11, 2017.

5. WHO. Guidelines for drinking-water quality 2011.

6. NEKOUEI S., NEKOUEI F., TYAGI I., AGARWAL S., GUPTA V.K. Mixed cloud point/solid phase extraction of lead(II) and cadmium(II) in water samples using modified$\mathrm{ZnO}$ nanopowders. Process Safety and Environmental Protection. 99, 175, 2016.

7. JOHRI N., JACQUILLET G., UNWIN R. Heavy metal poisoning: the effects of cadmium on the kidney. BioMetals. 23 (5), 783, 2010.

8. TOUNSADI H., KHALIDI A., ABDENNOURI M., BARKA N. Biosorption potential of Diplotaxis harra and Glebionis coronaria L. biomasses for the removal of $\mathrm{Cd}(\mathrm{II})$ and $\mathrm{Co}(\mathrm{II})$ from aqueous solutions. Journal of Environmental Chemical Engineering. 3 (2), 822, 2015.

9. ZHANG M., WANG H., HAN X. Preparation of metalresistant immobilized sulfate reducing bacteria beads for acid mine drainage treatment. Chemosphere. 154, 215, 2016.

10. LI X., DAI L., ZHANG C., ZENG G., LIU Y., ZHOU C., XU W., WU Y., TANG X., LIU W., LAN S. Enhanced biological stabilization of heavy metals in sediment using immobilized sulfate reducing bacteria beads with inner cohesive nutrient. Journal of Hazardous Materials. 324, 340, 2017.

11. CRUZ VIGGI C., PAGNANELLI F., CIBATI A., UCCELLETTI D., PALLESCHI C., TORO L. Biotreatment and bioassessment of heavy metal removal by sulphate reducing bacteria in fixed bed reactors. Water research. 44 (1), 151, 2010.

12. AYALA-PARRA P., SIERRA-ALVAREZ R., FIELD J.A. Treatment of acid rock drainage using a sulfate-reducing bioreactor with zero-valent iron. Journal of Hazardous Materials. 308, 97, 2016.

13. ZHANG H., LI M., YANG Z., SUN Y., YAN J., CHEN D., CHEN Y. Isolation of a non-traditional sulfate reducingbacteria Citrobacter freundii sp and bioremoval of thallium and sulfate. Ecological Engineering. 102, 397, 2017.

14. VALO R.J., H GGBLOM M.M., SALKINOJA-SALONEN M.S. Bioremediation of chlorophenol containing simulated ground water by immobilized bacteria. Water research. 24 (2), 253, 1990.

15. BASKARAN V., NEMATI M. Anaerobic reduction of sulfate in immobilized cell bioreactors, using a microbial culture originated from an oil reservoir. Biochemical Engineering Journal. 31 (2), 148, 2006.

16. NECULITA C.M., ZAGURY G.J., BUSSI RE B. Passive treatment of acid mine drainage in bioreactors using sulfate-reducing bacteria: critical review and research needs. Journal of Environmental Quality. 36 (1), 1, 2007.

17. NOPCHAROENKUL W., NETSAKULNEE P., PINYAKONG O. Diesel oil removal by immobilized Pseudoxanthomonas sp. RN402. Biodegradation. 24 (3), 387, 2013.

18. WILKINSON S.C., GOULDING K.H., ROBINSON P.K. Mercury removal by immobilized algae in batch culture systems. Journal of Applied Phycology. 2 (3), 223, 1990.

19. CHEN W., ZHANG H., CHEN Y. Effect of $\mathrm{pH}$, temperature and initial concentration on thallium removal by sulfatereducing bacteria. Chinese Journal of Environmental Engineering. 8 (10), 4105, 2014.

20. SUN J., LIU J., LIU Y., LI Z., NAN J. Optimization of Entrapping Conditions of Nitrifying Bacteria and Selection of Entrapping Agent. Procedia Environmental Sciences. 8, 166, 2011.

21. PAN X.L., WANG J.L., ZHANG D.Y. Biosorption of Pb (II) by Pleurotus ostreatus immobilized in calcium alginate gel. Process Biochemistry. 40 (8), 2799, 2005.

22. LI X.J., TANG D.L., TANG F., ZHU Y.Y., HE C.F., LIU M.H., LIN C.X., LIU Y.F. Preparation, characterization and photocatalytic activity of visible-light-driven plasmonic $\mathrm{Ag} / \mathrm{AgBr} / \mathrm{ZnFe}_{2} \mathrm{O}_{4}$ nanocomposites. Materials Research Bulletin. 56, 125, 2014.

23. KARATAY S.E., KILI N.K., D NMEZ, G. Removal of Remazol Blue by azoreductase from newly isolated bacteria. Ecological Engineering. 84, 301, 2015.

24. WILLOW M.A., COHEN R.R. pH, dissolved oxygen, and adsorption effects on metal removal in anaerobic bioreactors. Journal of Environmental Quality. 32 (4), 1212, 2003.

25. HAO O.J., CHEN J.M., HUANG L., BUGLASS R.L. Sulfate-reducing bacteria. Critical Reviews in Environmental Science and Technology. 26 (2), 155, 1996.

26. PARK Y.-J., KO J.-J., YUN S.-L., LEE E.Y., KIM S.-J., KANG S.-W., LEE B.-C., KIM S.-K. Enhancement of bioremediation by Ralstonia sp. HM-1 in sediment polluted by $\mathrm{Cd}$ and Zn. Bioresource Technology. 99 (16), 7458, 2008.

27. BAJPAI J., SHRIVASTAVA R., BAJPAI A.K. Dynamic and equilibrium studies on adsorption of $\mathrm{Cr}(\mathrm{VI})$ ions onto binary bio-polymeric beads of cross linked alginate and gelatin. Colloids and Surfaces A: Physicochemical and Engineering Aspects. 236 (1), 81, 2004.

28. HAO T.-W., XIANG P.-Y., MACKEY H.R., CHI K., LU H., CHUI H.-K., VAN LOOSDRECHT M.C. CHEN, G.-H. A review of biological sulfate conversions in wastewater treatment. Water research. 65, 1, 2014.

29. LONG J., LI H., JIANG D., LUO D., CHEN Y., XIA J., CHEN, D. Biosorption of strontium (II) from aqueous solutions by Bacillus cereus isolated from strontium hyperaccumulator Andropogon gayanus. Process Safety and Environmental Protection. 111, 23, 2017.

30. HUANG F., DANG Z., GUO C.-L., LU G.-N., GU R.R., LIU H.-J., ZHANG H. Biosorption of Cd (II) by live and dead cells of Bacillus cereus RC-1 isolated from cadmiumcontaminated soil. Colloids and Surfaces B: Biointerfaces. 107, 11, 2013. 
31. LI H., CHEN Y., LONG J., LI X., JIANG D., ZHANG P., QI J., HUANG X., LIU J., XU R., GONG J. Removal of thallium from aqueous solutions using Fe-Mn binary oxides. Journal of Hazardous Materials. 338, 296, 2017.

32. HO Y.S., MCKAY G. A kinetic study of dye sorption by biosorbent waste product pith. Resources Conservation \& Recycling. 25 (s 3-4), 171, 1999.

33. L PEZ P REZ P.A., AGUILAR L PEZ R., NERIA GONZ LEZ M.I. Cadmium removal at high concentration in aqueous medium: mediated by Desulfovibrio alaskensis. International Journal of Environmental Science and Technology. 12 (6), 1975, 2015.

34. HE J., CHEN J.P. A comprehensive review on biosorption of heavy metals by algal biomass: materials, performances, chemistry, and modeling simulation tools. Bioresource technology. 160, 67, 2014.

35. CRUZ C.C., DA COSTA A.C.A., HENRIQUES C.A., LUNA A.S. Kinetic modeling and equilibrium studies during cadmium biosorption by dead Sargassum sp. biomass. Bioresource Technology. 91 (3), 249, 2004.

36. PARDO R., HERGUEDAS M., BARRADO E., VEGA M. Biosorption of cadmium, copper, lead and zinc by inactive biomass of Pseudomonas putida. Analytical and bioanalytical chemistry. 376 (1), 26, 2003.

37. SAPRA S., NANDA J., SARMA D., EL-AL F.A., HODES G. Blue emission from cysteine ester passivated cadmium sulfide nanoclusters. Chemical Communications. (21), 2188, 2001.

38. NAUMANN A. Fourier Transform Infrared (FTIR) Microscopy and Imaging of Fungi. In: Dahms TES, Czymmek KJ, editors. Advanced Microscopy in Mycology. Cham: Springer International Publishing; 61, 2015.

39. CAO J.-J., JIANG Z.-T., XIONG Z.-H., YANG Y.-N., CHEN S.-Y. Study on Infrared Spectra Characteristics of Fault Particles of the Sulfide Deposit. Spectroscopy and Spectral Analysis. 29 (4), 956, 2009.
40. MARYCHURCH M., MORRIS G. X-ray photoelectron spectra of crystal and thin film cadmium sulphide. Surface Science Letters. 154 (2-3), L251, 1985.

41. YU J., YU Y., ZHOU P., XIAO W., CHENG B. Morphologydependent photocatalytic H2-production activity of CdS. Applied Catalysis B: Environmental. 156, 184, 2014.

42. HOTA G., IDAGE S.B., KHILAR K.C. Characterization of nano-sized $\mathrm{CdS}-\mathrm{Ag}_{2} \mathrm{~S}$ core-shell nanoparticles using XPS technique. Colloids and Surfaces A: Physicochemical and Engineering Aspects. 293 (1), 5, 2007.

43. BRION D. Photoelectron spectroscopic study of the surface degradation of pyrite $\left(\mathrm{FeS}_{2}\right)$, chalcopyrite $\left(\mathrm{CuFeS}_{2}\right)$, sphalerite $(\mathrm{ZnS})$, and galena $(\mathrm{PbS})$ in air and water. Applications of Surface Science. 5 (2), 133, 1980.

44. DE BARROS M.I., BOUCHET J., RAOULT I., LE MOGNE T., MARTIN J.M., KASRAI M., YAMADA Y. Friction reduction by metal sulfides in boundary lubrication studied by XPS and XANES analyses. Wear. 254 (9), 863, 2003.

45. DOU B., JIANG X., WANG X., TANG L., DU Z. Synthesis and photoelectric properties of cadmium hydroxide and cadmium hydroxide/cadmium sulphide ultrafine nanowires. Physica B: Condensed Matter. 516, 72, 2017.

46. SETTY M.S., SINHA A.P.B. Characterization of highly conducting $\mathrm{PbO}$-doped $\mathrm{Cd}_{2} \mathrm{SnO}_{4}$ thick films. Thin Solid Films. 144 (1), 7, 1986.

47. WANG F.-Z., SHANG D.-C., WANG M.-G., HU S.-G., LI Y.-Q. Incorporation and substitution mechanism of cadmium in cement clinker. Journal of Cleaner Production. 112, 2292, 2016.

48. LIM S.-F., ZHENG Y.-M., ZOU S.-W., CHEN J.P. Characterization of Copper Adsorption onto an Alginate Encapsulated Magnetic Sorbent by a Combined FT-IR, XPS, and Mathematical Modeling Study. Environmental Science \& Technology. 42 (7), 2551, 2008. 
